\title{
Earthly Delights, Economies and Cultures of Food in Ottoman and Danubian Europe, c. 1500-1900. Edited by Angela Jianu and Violeta Barbu. Leiden-Boston: Brill, 2018. 534 pp.
}

The absence of modern writing on Eastern European food history is sometimes rather conspicuous. It was therefore a pleasant surprise to find that Brill has recently published a volume titled Earthly Delights, Economies and Cultures of Food in Ottoman and Damubian Europe, c. 1500-1900, which is part of its Balkan Studies Library series. The volume, edited by Angela Jianu and Violeta Barbu, contains 17 studies by various authors spanning 534 pages and comes with color illustrations and a general index at the end. The collection starts with the editors' introduction, which is well written and informative. There are also brief biographies of the participating authors, a short historical chronology of the Balkans starting from 1456, and notes on translation and transliteration.

The project was divided into five thematic parts, each containing two to five studies. The first part focuses on the Ottoman world, the second deals with ingredients and kitchens, the third shifts its attention to trade and food supply, the fourth discusses local cookbooks, and the last part examines the issue of representation, in other words how Balkan food, cooking, and (in)hospitality were perceived by foreign observers.

The essays in the collection generally speaking fall into two categories. Some authors strove to present the reader with an overview of a broadly outlined topic, like Moldavian or Wallachian cuisine in the early modern era, while others delved deep into the details of one particular theme, e. g. when and how olive oil replaced butter as the primary source of fat in Turkey. In the following paragraphs, I briefly comment on each study and then share a few general remarks.

After the excellent introduction by the editors, the first study written by Suraiya Faroqhi from Istanbul Bilgi University deals with the gradual introduction of olive oil into Turkish cuisine. It presents an interesting perspective, demonstrating that the dominance of olives was not as absolute as one would have expected in this area based on what we know about ancient Roman and, later, Italian cuisine. It also introduces the topic of cultural resistance, when Faroqhi explains that the relative reluctance of Turks to use olive oil as a staple of Mediterranean cuisine might have been caused by its popularity among Greeks.

The next study, by Hedda Reindl-Kiel, provides a well-written overview of the sources available on Early Modern Eastern cuisine, including a seventeenth- 
century Persian cookbook, shopping bills, and lists of food distribution from the sultan's court. This last item is particularly illuminating, and Reindl-Kiel demonstrates how food distributed in the upper echelons of Ottoman society surpassed simple nutritional functions and gained an important symbolic value. As reports written by contemporary European observers, such as the one by the Habsburg ambassador to the High Porte, Heøman Ėernín of Chudenice (1576-1651), suggest, foreigners often misunderstood the distinctive role of food in Turkish society.

Özge Samanc1's chapter on cuisine in nineteenth-century Istanbul lists a broad variety of foodstuffs utilized in early Turkish printed cookbooks, the oldest of which appeared in 1840. Margareta Aslan's work contains a discussion on the history of food in Transylvania with particular focus on Turkish influence. She points out some interesting comparative differences in food culture between Romanians, Turks, and Hungarians (e. g. the use of sweeteners in certain contexts or diverging preferences for various spices in the Balkan regions). The first part of the collection comes to a close with an essay by Olivia Senciuc dealing with the attractive theme of coffee and tea in eighteenth-century Moldavia and Wallachia. Perhaps Senciuc's most interesting conclusion is the realization that despite the constant Ottoman political, economic, and military influence, the wealthy boyar families began to consume coffee relatively late, only in the second half of the seventeenth century, which coincided with the adoption of caffeinated drinks by upper classes in the other regions of Central and Eastern Europe.

The second section of the book, titled "Ingredients, Kitchens and the Pleasures of the Table," opens with Kinga S. Tüdõs's study of early modern festivities in Transylvania. For a readership particularly interested in Hungarian culture, this is perhaps the most relevant passage, as Tüdõs brings into focus the Hungarian group of east Transylvanians, called Székelys. Tüdõs's extensive use of inheritance inventories resembles similarly oriented research on the cultural history of the dining customs of the early modern noble classes, which became a subject of considerable interest in Bohemia in the 1990s and early 2000s. ${ }^{1}$ The study draws heavily on the manuscript cookbook of Princess

1 For example, South Bohemian nobility was discussed by Václav Bůžek and Josef Hrdlička, eds., Dvory

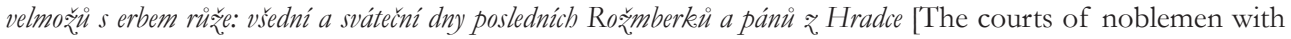
rose in the coat of arms: mundane and festive days of the last members of Rosenbergs and lords of Hradec] (Praha: Mladá fronta, 1997); Václav Bůžek and Pavel Král, eds., Slavnosti a qábavy na dvorech a v rezidenčnich mëstech raného novověku [Festivities and entertainment at courts and residences in early modern period] (České Budějovice: Historický ústav Jihočeské univerzity, 2000). 
Anna Bornemisza (1630-1688), which prompts me to suggest that it might be beneficial to compare this source with a collection of three mid-seventeenthcentury handwritten cookbooks attributed to the Czech nobility and preserved in the National Museum and Strahov Library in Prague. These Czech collections are nearly contemporary to Anna Bornemisza's cookbook and reflect a similar socioeconomic background.

The following study by Maria Magdalena Székely draws the readers' attention to another historical region, the principality of Moldavia. Székely does not rely exclusively on the scarce written historical records, but also introduces information gleaned from archeological, archaeobotanical, and archeozoological sources which provide an additional perspective. Székely's work offers a comparative analysis of early modern food culture in Moldavia, which will help other Central and Eastern European historians better contextualize their own research. Violeta Barbu, the author of the next study on early modern food culture in Wallachia, uses an equally broad approach, basically providing a textbook-like delineation usable by any historian searching for comparisons with findings in their own research. Like Székely, Barbu also makes creative use of the sources, for example Rituale Romanum.

From the conceptually broad studies, we move back towards microhistory at the beginning of the third part of the collection. It begins with a paper by Enikõ Rüsz-Fogarasi describing food supply in the Romanian city of Cluj in the early modern period, in which Rüsz-Fogarasi builds on her previous interest in the history of hospitals in Transylvania. This text is valuable for its focus on a comparatively early period (1550-1650), but it also shows how challenging it is to work with relatively scarce written sources. Analogically, Mária PakucsWillcocks's study focuses on a single Transylvanian place as well, the city of Sibiu. Her paper therefore works very well in comparison with the previous chapter. Pakucs-Willcocks begins with an examination of import fees and other legal contexts for trade with the Ottomans and later delves into detail when discussing the individual types of food. I would highlight her attempt to shape often limited sources into series of data, systematically tracking certain commodities.

While the two previous studies dealt with trade more or less exclusively in Transylvania, Gheorghe Lazãr's paper shifts the focus to trade in eighteenthcentury and nineteenth-century Wallachia. Lazãr divides his interest between what he calls "the big retail trade," which means the export of horses, cattle, and grain and "the small trade," referring to the import of luxury goods. Both 
are equally valuable, but quite distinct from the perspective of writing about the history of food culture, as they offer testimony to differing socioeconomic realities.

The fourth section of the book, which is also the shortest, consists of two chapters examining historical Balkan cookbooks. First, Castilia Manea-Grgin describes two early modern handwritten collections of recipes: "Compendium on the Preparation of Day-to-Day Dishes," owned originally by Miklós Zrínyi (1620-1664), and the slightly more recent "Book in which Dishes of Fish, Crayfish, Oysters, Snails, Vegetables, Herbs, and Other Dishes for Fast and Nonfast Days are Written, In their Due order." The origin of this second manuscript is uncertain, but it is likely a seventeenth-century source possibly linked to Constantin Cantacuzino, who served between 1675-1677 as the Great Steward to the Wallachian princes. It is worth noting, however, that the analysis avoids the food-related parts of both collections, focusing instead on related topics, such as the management of orchards, gardening, and viniculture. Nevertheless, the study is still quite useful for food historians, because these topics are related to the history of nutrition, and Manea-Grgin also provides a thorough examination of the foreign influences she was able to detect, particularly in the Romanian collection.

In the following article, Stefan Detchev writes about the oldest printed cookbooks in Bulgaria, which were published in the 1870s. As this is a very modern topic, it is well outside my area of expertise, but I imagine that a comparative study with other cookbooks of the period, for example, might yield interesting findings related to the birth of modern femininity in the Central and Eastern European context.

The introductory study of the last section was written by Andrew Dalby, the prolific British historian of food, who examines several travelogues written by foreigners about their stays in late eighteenth-century and nineteenth-century Romania. Although mostly focused on modern history, this chapter does occasionally delve into much older, seventeenth-century reports by William Lithgow, John Smith (of Pocahontas fame), Robert Bargrave, and Edmund Chishull. Dalby's text is an excellent read and very entertaining, though it does present (understandably) an exclusively outsider's perspective of the Balkans, as Dalby does not read local sources.

Fortunately, Angela Jianu, the author of the following chapter, addresses this issue in her analysis of travelogues from the mid-nineteenth century. Unlike Dalby, Jianu provides feedback on information published by the travelers mentioned 
in her paper. She also pays careful attention to concepts like "commensality" and "otherness" in the Balkans, which she describes as a region "in-between" the East and the West. The penultimate study by Anna Matthaiou draws on a plethora of information concerning modern food culture in the Balkans, while also commenting on its fractured nature. This study chronologically extends well into the twentieth century and provides interesting insights into the construction of Hellenized "national" cuisine and the homogeneity versus the diversity of local traditions.

Finally, Andrei Oi'teanu draws the readers' attention to the Jewish tavernkeepers in Romania with an emphasis on prejudice and stereotypes associated with the life of this minority in nineteenth-century Eastern Europe. His chapter also brings up broader contexts and is worth reading for those interested in Judaic history from the seventeenth century to the twentieth.

Overall, Earthly Delights presents an intriguing and critically important collection of studies. The volume is well organized, and the shortcomings to which a reviewer might draw attention are only minor. There are a few typographical errors, but not more than one would expect in such large project. I particularly appreciate the fact that most of the studies were written by authors with clear links to the Balkans and not by foreigners theorizing about the region. This is necessary due to the difficult linguistic landscape of the region, as shown for example by the painstakingly documented trilingual toponyms in passages related to Transylvania.

For foreigners like me, the study highlights certain issues inherent to Balkan historiography. For example, I find it interesting to observe the propensity of Romanian historiography towards the French theoretical tradition of the Annales school. In Czech historiography, this source of inspiration is filled mostly by German scholars and, recently, the growing importance of English historical writing.

Another general observation I would make concerns the relative lack of written sources, which became more abundant only after the mid-seventeenth century. It can be partially supplemented by archeological and archaeobotanical findings, but I suspect that this form of research requires levels of funding which are not yet readily available in Eastern Europe.

Perhaps the most striking feature is visible particularly in the final chapters, where readers are continually reminded of the Protean nature of the Balkans as a simultaneously backward, static place where time stands still (and good inns are hard to come by), while it was also a place of tumultuous change in a "melting 
pot" of cultures, nationalities, religions, languages, and political interests. The editors appropriately reflect on this phenomenon in the introduction when they claim that globalization and multiculturalism are not modern inventions, as regions like Transylvania were faced with similar challenges centuries before these terms became fashionable, contentious issues for present culture wars. Overall, Earthly Delights is an essential read for any historian of food, especially a historian focusing on the seventeenth century and later periods.

\author{
Karel Černý \\ Charles University \\ karel.cerny@lf1.cuni.cz
}

